\title{
FORMULATION AND OPTIMIZATION OF VARDENAFIL HYDROCHLORIDE ORAL DISINTEGRATING TABLETS: EFFECT OF SUPERDISINTEGRANTS
}

\author{
BY \\ Hossameldin M. Kadry, Alaa A.Zaky, Alaa A.Kassem \\ FROM \\ Department of pharmaceutics and Industrial Pharmacy, \\ Faculty of Pharmacy, Al-Azhar University
}

\begin{abstract}
One of the fruitful results of oral technological advancement in dosage forms is the orally disintegrating tablets (ODTs) as they disintegrate rapidly in the mouth and do not require water for administration. This work employed mixture design approach for developing and optimizing oral disintegrating tablets of a slightly water soluble drug, vardenafil hydrochloride. Three component mixture design was used to optimize the type and concentration of superdisntegrants, crosscarmellose sodium $\left(\mathrm{X}_{1}\right)$, crosspovidone $\left(\mathrm{X}_{2}\right)$ and sodium starch glycolate $\left(\mathrm{X}_{3}\right)$ using water soluble dextrates $\left(\right.$ Emdex $\left.^{\circledR}\right)$ as a filler. Disintegration time, wetting time and t90 $_{90}$ values for all formulations ranged from 33.69 to $208.68 \mathrm{~s}, 40.42$ to $209.83 \mathrm{~s}$ and 80.04 to $484.63 \mathrm{~s}$, respectively. According to the results, the selected variables have a strong influence on disintegration time, wetting time and $t_{90}$ of the ODTs. The lowest disintegration time, wetting time and $t_{90}$ were showed by ODTs formula composed of $1.72 \%$ of crosscarmellose in combination with $4.28 \%$ of crosspovidone. So, this formula was chosen as the optimized formula. Stability studies also showed that the optimized formula was stable under accelerated conditions. And, by comparing the selected formula with Prosolv ${ }^{\circledR}$ ODT G2 as a ready ODT system, it showed faster disintegration time and higher dissolution rate. Hence, the best superdisintegrants to be used with the water soluble dextrates are crosspovidone in combination with crosscarmellose sodium.
\end{abstract}

Keywords: Oral disintegrating tablets, mixture design, vardenafil hydrochloride, dextrates (Emdex), Prosolv ODT, crosscarmellose sodium, crosspovidone, sodium starch glycolate.

\section{INTRODUCTION}

Over the past three decades, orally disintegrating tablets (ODTs) have gained considerable attention as a preferred alternative to conventional tablets and capsules due to better patient compliance (Ganesh and Deshpande 2011). ODTs are solid dosage forms containing medicinal substances which disintegrate rapidly, usually in a matter of seconds, when placed on the tongue (Hirani et al. 2009). These dosage forms are of particular advantages in certain patient groups who have difficulty in swallowing such as pediatric, geriatric and psychiatric patients (Sastry et al. 2000, Suresh et al. 2008). ODTs are formulated in such a way that they disperse, dissolve, or disintegrate rapidly in oral cavity, allowing release of the medication from the dosage form without water. This attributed to rapid water absorption into the core of the tablets, rapid disintegration of 
tablets and dissolving water soluble tablet components which leads to rapid dissolution of the tablets (Velmurugan and Vinushitha 2010). Dissolved medication either swallowed or subjected to pregastric absorption which may lead to increasing the rate and extent of drug absorption and may decrease hepatic metabolism (Van Arnum 2007).

Three main manufacturing methods are used for the manufacturing of different technologies of ODTs. These methods are: freeze drying(Ghosh et al. 2011), molding(Fu et al. 2004) and compression method (Wagh et al. 2010). To develop a rapidly disintegrating tablet with direct-compression method, it was necessary to find suitable excipients with good compressibility and disintegrating ability. Although the superdisintegrants primarily affect the rate of disintegration, when used at high concentrations, they can also affect mouth feel, tablet hardness, and friability. Thus, several factors must be considered when selecting a superdisintegrant (Abdelbary et al. 2009). The direct-compression tablet's disintegration and dissolution are based on the single or combined action of disintegrants and water-soluble excipients. In many cases, the disintegrants have a major role in the disintegration/dissolution process of rapidly disintegrating tablets made by direct compression. The choice of a suitable type and an optimal amount of disintegrants is paramount for ensuring a high disintegration rate (Dobetti 2001). The simultaneous presence of a disintegrant with a high swelling (or disintegrating) force, defined as "disintegrating agent" and a substance with a low swelling force, defined as "swelling agent," was claimed as the key factor for the rapid disintegration of a tablet, also offering satisfactory physical resistance (Cousin et al. 1995).

ODTs formulations have the advantages of both solid and liquid dosage forms and are useful for immediate release of drug with improved bioavailability enabling reduction of the therapeutic dose with almost the same pharmacological action; as higher doses from conventional dosage forms, and decreasing the adverse effects (Mostafa et al. 2013).

Vardenafil is an oral therapy for the treatment of erectile dysfunction. It is a selective inhibitor of cyclic guanosine monophosphate (cGMP) specific phosphodiesterase type 5 (PDE5) which is the most abundant PDE in the human corpus cavernosum (DrugBank 2016).

A mixture design approach was used to optimize the type and concentration of superdisintegrants in developing using water soluble filler (dextrates). Simplex centroid mixture design was applied to optimize the concentration of crosscarmellose sodium $\left(\mathrm{X}_{1}\right)$, crosspovidone $\left(\mathrm{X}_{2}\right)$ and sodium starch glycolate $\left(\mathrm{X}_{3}\right)$. Special cubic model with interaction terms was derived to evaluate the effect of the three components on ODTs disintegration time $\left(\mathrm{Y}_{1}\right)$, wetting time $\left(\mathrm{Y}_{2}\right)$ and time for $90 \%$ release of the drug $\mathrm{t}_{90}\left(\mathrm{Y}_{3}\right)$. The effect of lower and higher superdisintegrant concentrations were also investigated for the optimized formula. Furthermore, the optimized formula was subjected to accelerated stability conditions and finally it was compared with Prosolv ${ }^{\circledR}$ ODT G2 as a ready ODT system.

\section{Materials and methods}

\section{Materials}

Vardenafil hydrochloride (B.N: UT2130408, Exp: March 2018) was kindly supplied by Marcyrl (Obour City, Egypt). Dextrates (Emdex®), Sodium stearyl fumarate (Pruv $\AA)$, crosscarmellose sodium (Vivasol $\left.{ }^{\circledR}\right)$, sodium starch glycolate (Explotab $\left.{ }^{\circledR}\right)$ and 
Prosolv® ODT G2 were kindly supplied by JRS (Aalen, Germany). Crosspovidone was received from Sigma for pharmaceutical Industries (Cairo, Egypt). Spray dried mannitol (MannogemTM EZ) was kindly supplied by SPI (Grand Haven, MI, USA).

\section{Methods}

\section{Precompression parameters}

\section{Bulk Density}

Apparent bulk density $(\rho b)$ was determined by pouring blend into a graduated cylinder. The bulk volume $(\mathrm{Vb})$ and weight of powder $(\mathrm{M})$ was determined. The bulk density was calculated using the formula (USP30-NF25 2007)

$$
\rho b=\mathrm{M} / \mathrm{Vb}
$$

\section{Tapped Density}

The measuring cylinder containing known mass of blend was tapped for a fixed time. The minimum vo-lume $(\mathrm{Vt})$ occupied in the cylinder and weight $(\mathrm{M})$ of the blend as measured. The tapped density ( $\rho$ t) was calculated using the formula (USP30-NF25 2007)

$$
\rho t=M / V t
$$

\section{Hausner ratio}

Hausner ratio is an indirect index of ease of powder flow. It is calculated by the following formula (USP30-NF25 2007)

$$
\text { Hausner ratio }=\rho t / \rho b
$$

Where $\rho t$ is tapped density and $\rho b$ is bulk density. Lower hausner ratio $(<1.25)$ indicate better flow prop-erties than higher ones $(>1.25)$.

\section{Carr's index}

The compressibility index of blend can be determined using Carr's compressibility index, and can be determined by the following formula (USP30-NF25 2007):

$$
\text { Carr's index }=[(\rho t-\rho b) / \rho t] \times 100
$$

\section{Preformulation study by DSC}

DSC studies were carried out using (Shimadzu DTA-50 Analyzer, Kyoto, Japan) to check the compatibility of ingedients. DSC thermograms of pure drug (vardenafil hydrochloride), crosscarmellose sodium, crosspovidone, sodium starch glycolate, dextrates, mannitol and sodium stearyl fumarate were obtained. Approximately $5 \mathrm{mg}$ of samples were weighed and placed in the aluminum pans and heated at a rate of $10{ }^{\circ} \mathrm{C} / \mathrm{min}$, with indium in the reference pan; in an atmosphere of nitrogen to a temperature $350{ }^{\circ} \mathrm{C}$. The DSC studies were performed for vardenafil hydrochloride and physical mixture of vardenafil hydrochloride with the investigated excipients.

\section{Experimental design}

Three component simplex centroid mixture design was used to optimize crosscarmellose sodium, CCS $\left(\mathrm{X}_{1}\right)$, crosspovidone, $\mathrm{CP}\left(\mathrm{X}_{2}\right)$ and sodium starch glycolate, SSG $\left(\mathrm{X}_{3}\right)$ concentrations using a statistical package (Design-Expert® Version 7.0.0). Binary and tertiary interaction terms were derived for the statistical models to evaluate the 
effect of the three components on ODTs disintegration time $\left(\mathrm{Y}_{1}\right)$, wetting time $\left(\mathrm{Y}_{2}\right)$ and time for $90 \%$ drug release, $\mathrm{t}_{90}\left(\mathrm{Y}_{3}\right)$.

The three independent variables as well as their proportions and the analyzed responses are shown in table (1); the matrix of the simplex centroid mixture design is represented in table (2), while the tablet formulations are represented in table (3).

A polynomial function is usually used to describe the response in a mixture experiment. This polynomial function represents how the components affect the response. To better study the shape of the response surface, the natural choice for a design would be the one whose points are spread evenly over the whole simplex. A simplex centroid design only includes the centroid points. Since a simplex centroid design usually has fewer runs than a simplex lattice design with the same degree, a polynomial model with fewer terms should be used. A simplex centroid design can be used to fit the following model.

$$
Y=\beta_{1} X_{1}+\beta_{2} X_{2}+\beta_{3} X_{3}+\beta_{12} X_{1} X_{2}+\beta_{13} X_{1} X_{3}+\beta_{23} X_{2} X_{3}+B_{123} X_{1} X_{2} X_{3}
$$

The above model is called the special cubic model. The intercept term is not included due to the correlation between the three components (their sum is 100\%).

Table (1): Variables in simplex centroid mixture design.

\begin{tabular}{|cllc|}
\hline Components & Low & High & Units \\
\hline $\mathrm{X}_{1}$ : Croscarmellose Sodium (CCS) & 0 & 6 & $\%$ \\
$\mathrm{X}_{2}$ : Crospovidone (CP) & 0 & 6 & $\%$ \\
$\mathrm{X}_{3}$ : Sodium starch glycolate (SSG) & 0 & 6 & $\%$ \\
Mixture Total $=6 \%$ & & & \\
\hline Dependent variable, Response & & & \\
$\mathrm{Y}_{1}:$ Disintegration time (sec) & & \\
Y2: Wetting time (sec) & & \\
Y3: t t $_{90}(\mathrm{sec})$ & & \\
\end{tabular}

Table (2): Matrix of simplex centroid mixture design for ODTs formualtions.

\begin{tabular}{|c|c|c|c|}
\hline Experiment No. & $\begin{array}{c}\text { Crosscarmellose } \\
\text { sodium }\left(X_{1}\right)\end{array}$ & Crospovidone $\left(X_{2}\right)$ & $\begin{array}{c}\text { Sodium Starch } \\
\text { Glycolate }\left(X_{3}\right)\end{array}$ \\
\hline $\mathbf{1}$ & 6 & 0 & 0 \\
\hline $\mathbf{2}$ & 0 & 6 & 0 \\
\hline $\mathbf{3}$ & 0 & 0 & 6 \\
\hline $\mathbf{4}$ & 3 & 3 & 3 \\
\hline $\mathbf{5}$ & 3 & 0 & 3 \\
\hline $\mathbf{6}$ & 0 & 3 & 2 \\
\hline $\mathbf{7}$ & 2 & 2 & \\
\hline
\end{tabular}




\begin{tabular}{|c|c|c|c|}
\hline $\mathbf{8}$ & 4 & 1 & 1 \\
\hline $\mathbf{9}$ & 1 & 4 & 1 \\
\hline $\mathbf{1 0}$ & 1 & 1 & 4 \\
\hline
\end{tabular}

Table (3): Vardenafil Hydrochloride ODTs Formulations.

\begin{tabular}{|l|c|}
\hline Ingredient & Weight $^{\mathbf{a}}(\boldsymbol{\%})$ \\
\hline Vardenafil HCl & 11.85 \\
\hline Emdex & 40 \\
\hline Superdisintegrant(s) & 6 \\
\hline Sodium Stearyl Fumarate & 0.5 \\
\hline Mannitol & To 100 \\
\hline
\end{tabular}

${ }^{\mathrm{a}}$ Tablet weight $=100 \mathrm{mg}$

\section{Tablet manufacturing}

ODTs were manufactured by direct compression method. The composition of vardenafil hydrochloride OTDs tablet formulations is displayed in Table (3). The corresponding amounts of drug, filler (dextrates) and superdisintegrants (CCS, CP and SSG) were accurately weighed. The weighed powder excipients were transferred into Cube Mixer KB (Erweka, S2Y, Heusenstamm, Germany) and mixed for $5 \mathrm{~min}$. Thereafter, the corresponding amount of mannitol was accurately weighed, added to the mixture and the powder mixture was further mixed for $10 \mathrm{~min}$. The formula weight of sodium stearyl fumarate was mixed with the powder in the cube mixer for 2 min. Finally, the powder was compressed into tablets using Single stroke tablet compressing machine (Royal Artist, Mumbai, India) using 6-mm diameter rounded flat punches. The tablets were collected during compression for in-process testing (weight and hardness) and were stored in airtight high-density polyethylene (HDPE) bottles pending further testing (Mostafa, Ibrahim et al. 2013).

\section{Weight variation}

Twenty tablets from each batch were individually weighed and the average weight and standard deviation were reported (Rahman et al. 2012).

\section{Hardness}

Tablet hardness was determined using hardness tester PTB 311 (Pharma test $\mathrm{GmbH}$, Hainburg, Germany) for 10 tablets of each batch with known weight. The average hardness and standard deviation were reported.

\section{Friability}

Tablet friability was determined according to (USP30-NF25 2007). In brief, 20 tablets were weighed (W1) and placed into the Single drum automated friability tester (Pharma Test, Hainburg, Germany) that was rotated at $25 \mathrm{rpm}$ for $4 \mathrm{~min}$. The tablets then were reweighed after removal of fines (W2), and the friability was calculated by: 


$$
\mathrm{F}=[(\mathrm{W} 1-\mathrm{W} 2) / \mathrm{W} 1] \times 100
$$

\section{Content Uniformity}

Uniformity of dosage unit was assessed according to (USP30-NF25 2007) requirements. Twenty tablets were randomly selected and average weight was calculated and powdered in a glass mortar. Powder equivalent to $11.85 \mathrm{mg}$ of drug was weighed and dissolved in $100 \mathrm{ml}$ of $6.8 \mathrm{pH}$ phosphate buffer, filtered and drug content analyzed using UV spectrophotometer (Shimadzu 1800 dual beam, Kyoto, Japan) at a wavelength of 215 $\mathrm{nm}$. The drug concentration was measured using the constructed standard calibration curve.

\section{In vitro disintegration time}

In vitro disintegration test was assessed according to the (USP30-NF25 2007) requirements for immediate release tablets. One dosage unit was put in each of the six tubes of the basket. The apparatus (Pharmatest PTZ 3E, Hainburg, Germany) was operated, using distilled water as the immersion fluid, maintained at $37 \pm 2^{\circ} \mathrm{C}$. Time for complete disintegration of each table and standard deviation were calculated (Shoukri et al. 2009).

\section{In vitro dissolution studies}

In vitro drug release was performed for vardenafil hydrochloride tablets according to the (USP30-NF25 2007) "Dissolution procedure" for immediate release dosage forms. A minimum of 6 tablets of each formula were tested. The USP 30 (apparatus 2) paddle method was used. Dissolution was carried out in $500 \mathrm{ml}$ phosphate buffer $\mathrm{pH} 6.8 \pm 0.05$ to simulate saliva fluid. The paddle was rotated at $50 \mathrm{rpm}$ at $37 \pm 0.5{ }^{\circ} \mathrm{C}$. Samples were tested at specified time intervals $(0.5,1,1.5,2,3,4,5,6,8,10,15,20,25$ and $30 \mathrm{~min})$. Samples were adequately diluted and analyzed spectrophotometrically at wavelength 215 $\mathrm{nm}$.

\section{Wetting time and wetting ratio}

Ten milliliters of distilled water containing eosin, a water soluble dye, were placed in a Petri dish of $10 \mathrm{~cm}$ diameter containing circular tissue papers of $10 \mathrm{~cm}$ diameter. One tablet carefully placed in the center of the Petri dish and the time required for water to reach the upper surface of the tablet was noted as the wetting time. The test results are presented as mean value of three determinations \pm SD (Jonwal et al. 2010). The complete wetted tablet was then weighed. Water absorption ratio, $\mathrm{R}$, was determined according to the following equation:

$$
\mathrm{R}=\left[\left(\mathrm{W}_{\mathrm{a}}-\mathrm{W}_{\mathrm{b}}\right) / \mathrm{W}_{\mathrm{b}}\right] \times 100
$$

Where $\mathrm{W}_{\mathrm{b}}$ and $\mathrm{Wa}$ are tablet weights before and after water absorption, respectively.

\section{Stability study of the optimized ODTs formula}

In order to investigate effect of storage on the optimized formula, accelerated stability study was carried out at $40 \pm 2{ }^{\circ} \mathrm{C}$ in a humidity chamber having $75 \pm 5 \% \mathrm{RH}$. Samples were withdrawn after three months and evaluated for change in drug content, hardness and disintegration time. Also, the kinetic parameters were calculated. 


\section{Comparing the optimized ODTs formula with Prosolv ${ }^{\circledR}$ ODT as a ready ODT system.}

The optimized vardenafil hydrochloride ODTs formula was compared to Prosolv ${ }^{\circledR}$ ODT G2, a ready ODT system. Table (4) represents ODTs formula prepared by Prosolv ${ }^{\circledR}$ ODT. Prosolv ${ }^{\circledR}$ ODT G2 is composed of microcrystalline cellulose, colloidal silicon dioxide, mannitol, fructose and crospovidone manufactured using JRS Pharma's coprocessing technology. It is a high functionality excipient for orally disintegrating tablet formulation, development, and manufacture. Disintegration time, wetting time, $t_{90}$ and dissolution profiles were evaluated for both optimized formula and Prosolv ${ }^{\circledR}$ ODT.

Table (4): Vardenafil hydrochloride ODTs formula prepared by Prosolv ${ }^{\circledR}$ ODT.

\begin{tabular}{lc}
\hline Ingredient & Weight $^{a}(\%)$ \\
\hline Vardenafil Hydrochloride & 11.85 \\
Sodium Stearyl Fumarate & 0.5 \\
Prosolv® ODT G2 & To 100 \\
\hline${ }^{a}$ Tablet weight $=100 \mathrm{mg}$ &
\end{tabular}

Results \& discussion

\section{preformulation study by DSC}

DSC thermogram of vardenafil hydrochloride showed sharp endothermic peak at $227{ }^{\circ} \mathrm{C}$ corresponding to its melting point which indicates its crystallinity and purity, Figure (1.a) (DrugDetails 2016). DSC thermogram of crosscarmellose sodium, crosspovidone and sodium starch glycolate (Jagadish et al. 2010), Figures (1.b, 1.c and 1.d) showed broad endotherm at $64.68{ }^{\circ} \mathrm{C}, 60.33{ }^{\circ} \mathrm{C}$ and $63.56{ }^{\circ} \mathrm{C}$ respectively due to melting whereas during scanning of Emdex ${ }^{\circledR}$, endothermic peaks at $86.69{ }^{\circ} \mathrm{C}, 148.64{ }^{\circ} \mathrm{C}$ and $220.70{ }^{\circ} \mathrm{C}$ were observed, (Figure 1.e). DSC thermogram of mannitol showed endothermic peak at $169.11^{\circ} \mathrm{C}$, while DSC of sodium stearyl fumarate showed three endothermic peaks at $101.05^{\circ} \mathrm{C}, 139.14{ }^{\circ} \mathrm{C}$ and $201{ }^{\circ} \mathrm{C}$ and an exothermic peak at $246{ }^{\circ} \mathrm{C}$, Figures (1.f and 1.g), respectively.

As shown in figure (1), Physical mixture of each ingredient with drug showed their identical peaks at defined temperature range. Presence of all peaks indicates that all ingredients are compatible with drug. 


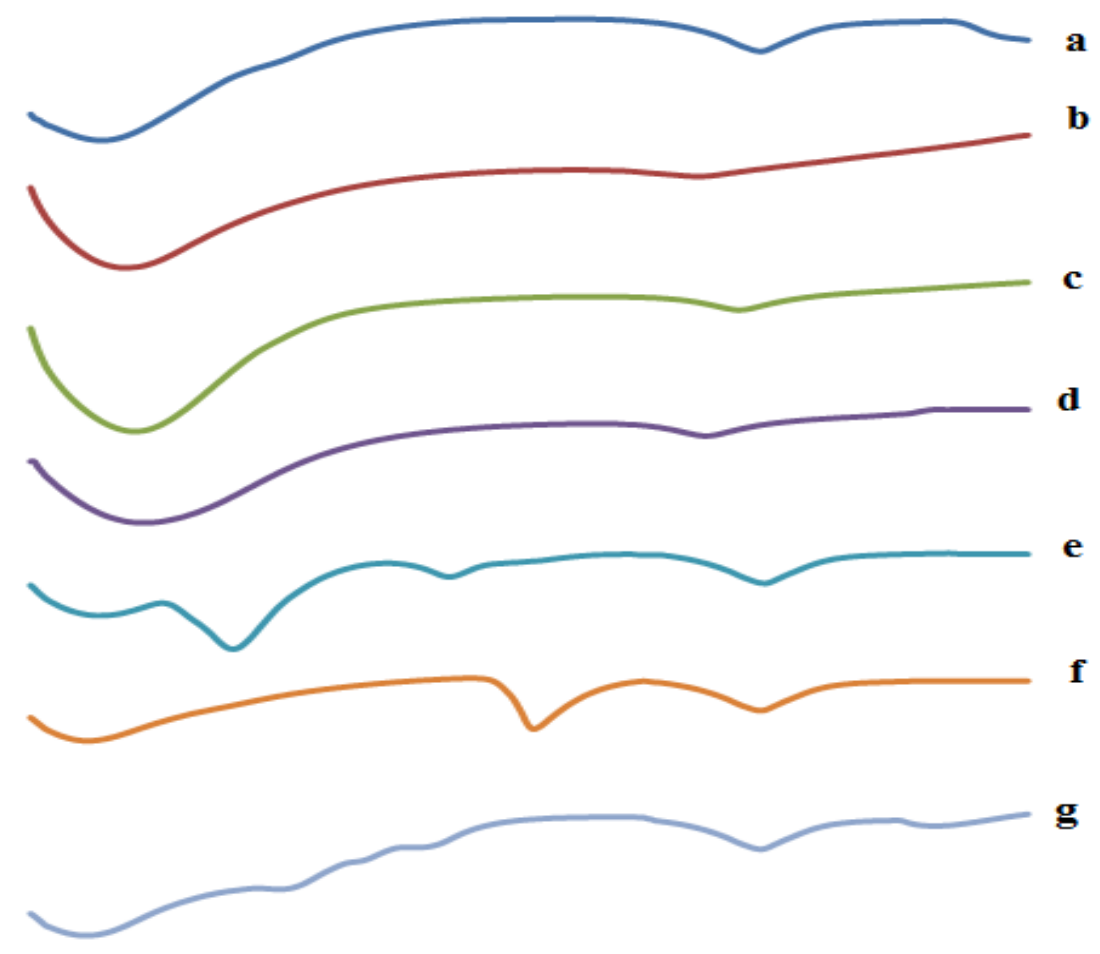

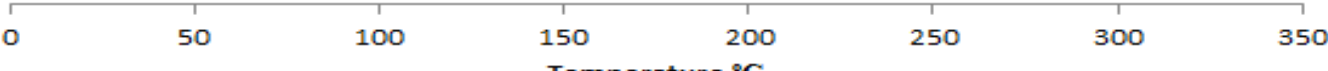

Figure (1): DSC thermogram of vardenafil hydrchloride plain powder (a), physical mixture with CCS (b), physical mixture with CP (c), physical mixture with SSG (d), physical mixture with Emdex ${ }^{\circledR}(\mathrm{e})$, physical mixture with mannitol (f) and physical mixture with SSF $(\mathrm{g})$.

\section{Data obtained from experimental design}

All tablet formulations were prepared according to the matrix of the design (Table 2) and according to formulae mentioned in Table (3). Vardenafil hydrochloride ODTs properties (weight, hardness, hausner ratio, carr's index, wetting time, wetting ratio and drug content) are summarized in Table (5) and the responses measured (disintegration "Y 1 ", wetting time "Y $Y_{2}$ " and time for $90 \%$ drug release "Y ${ }_{3}$ ") are summarized in Figure (2). All manufactured tablets formulations met the USP30-NF25 requirements for uniformity of dosage units. Acceptance values of all formulations were within the USP30NF25 limit and drug content was ranged from $98.21 \pm 0.841 \%$ to $102.82 \pm 1.162 \%$. Furthermore, all tablets friability was below $0.577 \%$ which compiles with USP requirements. Disintegration time, wetting time and $t_{90}$ values for all the ten formulations (Figure 2) varied from 33.69 to $208.68 \mathrm{sec}$., 40.42 to $209.83 \mathrm{sec}$. and 80.04 to $484.63 \mathrm{sec}$. respectively. These results indicate that the selected variables have strong influence on disintegration time, wetting time and $t_{90}$ of the ODTs. 
Table (5): Results of each experimental design run in simplex centroid mixture design of vardenafil hydrochloride ODTs.

\begin{tabular}{|c|c|c|c|c|c|c|c|c|}
\hline 昜 & $\begin{array}{l}\text { Weight } \\
\text { (mg) }\end{array}$ & $\begin{array}{c}\text { Hardness } \\
(\mathrm{Kp} \pm \mathrm{SD})\end{array}$ & $\begin{array}{c}\text { Friability } \\
(\%)\end{array}$ & $\begin{array}{c}\text { Hausner } \\
\text { ratio }\end{array}$ & $\begin{array}{l}\text { Carr's } \\
\text { Index }\end{array}$ & $\begin{array}{l}\text { Wetting } \\
\text { time } \\
(\text { sec. } \pm \text { SD) }\end{array}$ & $\begin{array}{l}\text { Wetting } \\
\text { ratio } \\
(\% \pm \mathrm{SD})\end{array}$ & $\begin{array}{c}\begin{array}{c}\text { Drug } \\
\text { content } \\
\text { uniformity }\end{array} \\
(\% \pm \mathrm{SD})\end{array}$ \\
\hline 1 & $\begin{array}{c}100.14 \pm \\
1.882\end{array}$ & $\begin{array}{l}3.03 \pm \\
0.513\end{array}$ & 0.353 & 1.126 & 11.2 & $\begin{array}{c}191.70 \pm \\
2.479\end{array}$ & $\begin{array}{l}8.99 \pm \\
3.345\end{array}$ & $\begin{array}{c}101.80 \pm \\
2.005\end{array}$ \\
\hline 2 & $\begin{array}{c}99.47 \pm \\
1.676\end{array}$ & $\begin{array}{c}3.07 \pm \\
0.321\end{array}$ & 0.415 & 1.106 & 9.6 & $\begin{array}{c}74.54 \pm \\
2.160\end{array}$ & $\begin{array}{c}42.13 \pm \\
2.819\end{array}$ & $\begin{array}{c}100.32 \pm \\
0.769\end{array}$ \\
\hline 3 & $\begin{array}{c}100.02 \pm \\
1.882\end{array}$ & $\begin{array}{l}3.13 \pm \\
0.493\end{array}$ & 0.196 & 1.128 & 11.4 & $\begin{array}{c}206.27 \pm \\
3.411\end{array}$ & $\begin{array}{c}13.33 \pm \\
0.908\end{array}$ & $\begin{array}{c}102.03 \pm \\
1.048\end{array}$ \\
\hline 4 & $\begin{array}{c}100.31 \pm \\
1.631\end{array}$ & $\begin{array}{c}3.03 \pm \\
0.300\end{array}$ & 0.383 & 1.059 & 5.6 & $\begin{array}{c}69.90 \pm \\
1.596\end{array}$ & $\begin{array}{c}28.14 \pm \\
0.814\end{array}$ & $\begin{array}{c}100.15 \pm \\
1.048\end{array}$ \\
\hline 5 & $\begin{array}{c}100.36 \pm \\
1.376\end{array}$ & $\begin{array}{c}2.97 \pm \\
0.351\end{array}$ & 0.338 & 1.123 & 11.0 & $\begin{array}{c}209.83 \pm \\
1.560\end{array}$ & $\begin{array}{c}30.70 \pm \\
1.168\end{array}$ & $\begin{array}{c}101.51 \pm \\
0.761\end{array}$ \\
\hline 6 & $\begin{array}{c}99.78 \pm \\
1.582\end{array}$ & $\begin{array}{c}2.89 \pm \\
0.551\end{array}$ & 0.454 & 1.120 & 10.7 & $\begin{array}{c}72.13 \pm \\
2.010\end{array}$ & $\begin{array}{c}32.80 \pm \\
2.013\end{array}$ & $\begin{array}{c}99.63 \pm \\
0.980\end{array}$ \\
\hline 7 & $\begin{array}{c}100.24 \pm \\
1.337\end{array}$ & $\begin{array}{c}2.99 \pm \\
0.361\end{array}$ & 0.318 & 1.126 & 11.2 & $\begin{array}{c}40.42 \pm \\
1.945\end{array}$ & $\begin{array}{c}35.61 \pm \\
0.794\end{array}$ & $\begin{array}{c}102.03 \pm \\
0.990\end{array}$ \\
\hline 8 & $\begin{array}{c}100.08 \pm \\
1.553\end{array}$ & $\begin{array}{c}3.20 \pm \\
0.529\end{array}$ & 0.577 & 1.112 & 10.0 & $\begin{array}{c}195.91 \pm \\
1.132\end{array}$ & $\begin{array}{c}32.89 \pm \\
2.390\end{array}$ & $\begin{array}{c}98.21 \pm \\
0.841\end{array}$ \\
\hline 9 & $\begin{array}{c}100.02 \pm \\
1.477\end{array}$ & $\begin{array}{c}3.00 \pm \\
0.115\end{array}$ & 0.519 & 1.125 & 11.1 & $\begin{array}{c}99.46 \pm \\
2.002\end{array}$ & $\begin{array}{c}35.23 \pm \\
1.152\end{array}$ & $\begin{array}{c}100.94 \pm \\
0.581\end{array}$ \\
\hline 10 & $\begin{array}{c}100.29 \pm \\
1.296\end{array}$ & $\begin{array}{c}3.17 \pm \\
0.404\end{array}$ & 0.317 & 1.123 & 11.0 & $\begin{array}{c}178.76 \pm \\
2.710\end{array}$ & $\begin{array}{c}26.31 \pm \\
1.899\end{array}$ & $\begin{array}{c}102.82 \pm \\
1.162\end{array}$ \\
\hline
\end{tabular}



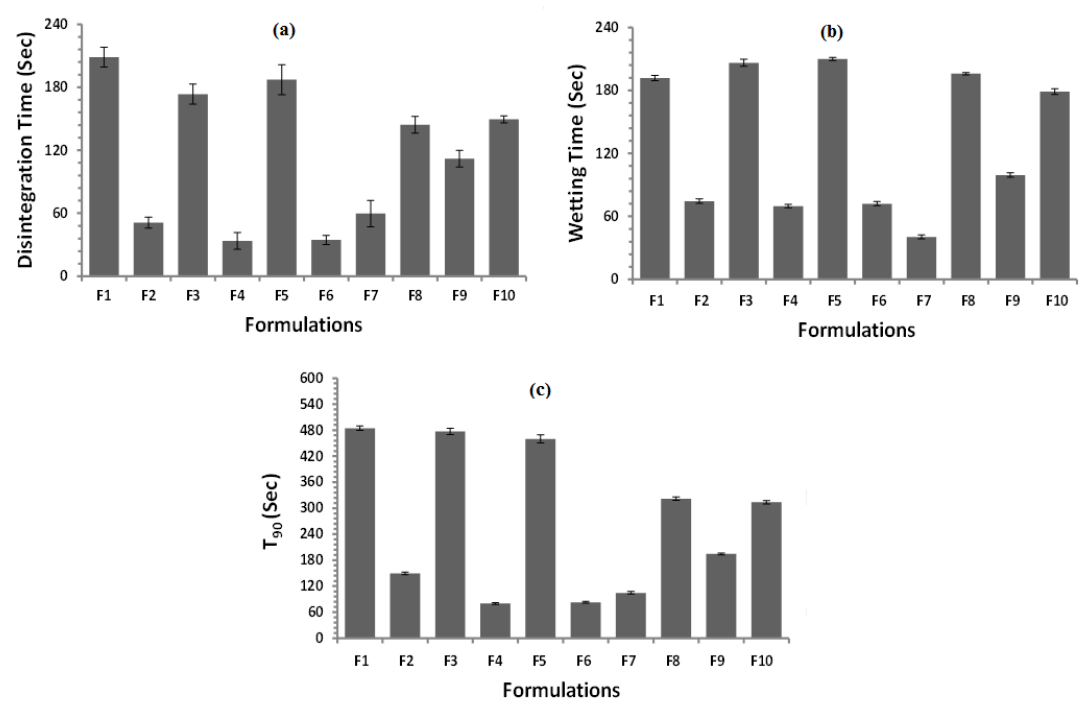

Figure (2): Histogram showing the disintegration time (a), wetting time (b) and $t_{90}$ (c) of vardenafil hydrochloride ODTs.

The resulting equations of analysis for each response variable were as follows:

$$
\begin{aligned}
& Y_{1}=205.39 X_{1}+67.18 X_{2}+174.66 X_{3}-359.26 X_{1} X_{2}-19.57 X_{1} X_{3}-276.11 X_{2} X_{3} \\
& +685.95 X_{1} X_{2} X_{3} \\
& Y_{2}=201.21 X_{1}+80.92 X_{2}+209.57 X_{3}-221.11 X_{1} X_{2}+69.35 X_{1} X_{3}-253.74 X_{2} X_{3} \\
& -563.42 X_{1} X_{2} X_{3} \\
& \text { (9) } \\
& Y_{3}=483.49 X_{1}+178.33 X_{2}+474.05 X_{3}-892.80 X_{1} X_{2}-92.91 X_{1} X_{3}-870.44 \\
& \mathrm{X}_{2} \mathrm{X}_{3}+178 \mathrm{X}_{1} \mathrm{X}_{2} \mathrm{X}_{3}
\end{aligned}
$$

The above equations were derived by the best-fit method to describe the main effect of process variables $\left(X_{1}, X_{2}\right.$ and $\left.X_{3}\right)$ and their interaction $\left(X_{1} X_{2}, X_{1} X_{3}, X_{2} X_{3}\right.$ and $\left.\mathrm{X}_{1} \mathrm{X}_{2} \mathrm{X}_{3}\right)$ on the responses $\left(\mathrm{Y}_{1}, \mathrm{Y}_{2}\right.$ and $\left.\mathrm{Y}_{3}\right)$. The values of the coefficients (regression coefficient) are associated with the effect of these variables on the response. Coefficients with more than one factor represent an interaction effect of two factors (e.g. $X_{1} X_{2}, X_{1} X_{3}$ and $X_{2} X_{3}$ ) while interaction of the three components (e.g. $X_{1} X_{2} X_{3}$ ) represent special cubic relationships. A positive sign reflects a synergistic effect while a negative sign stands for an antagonistic effect. 

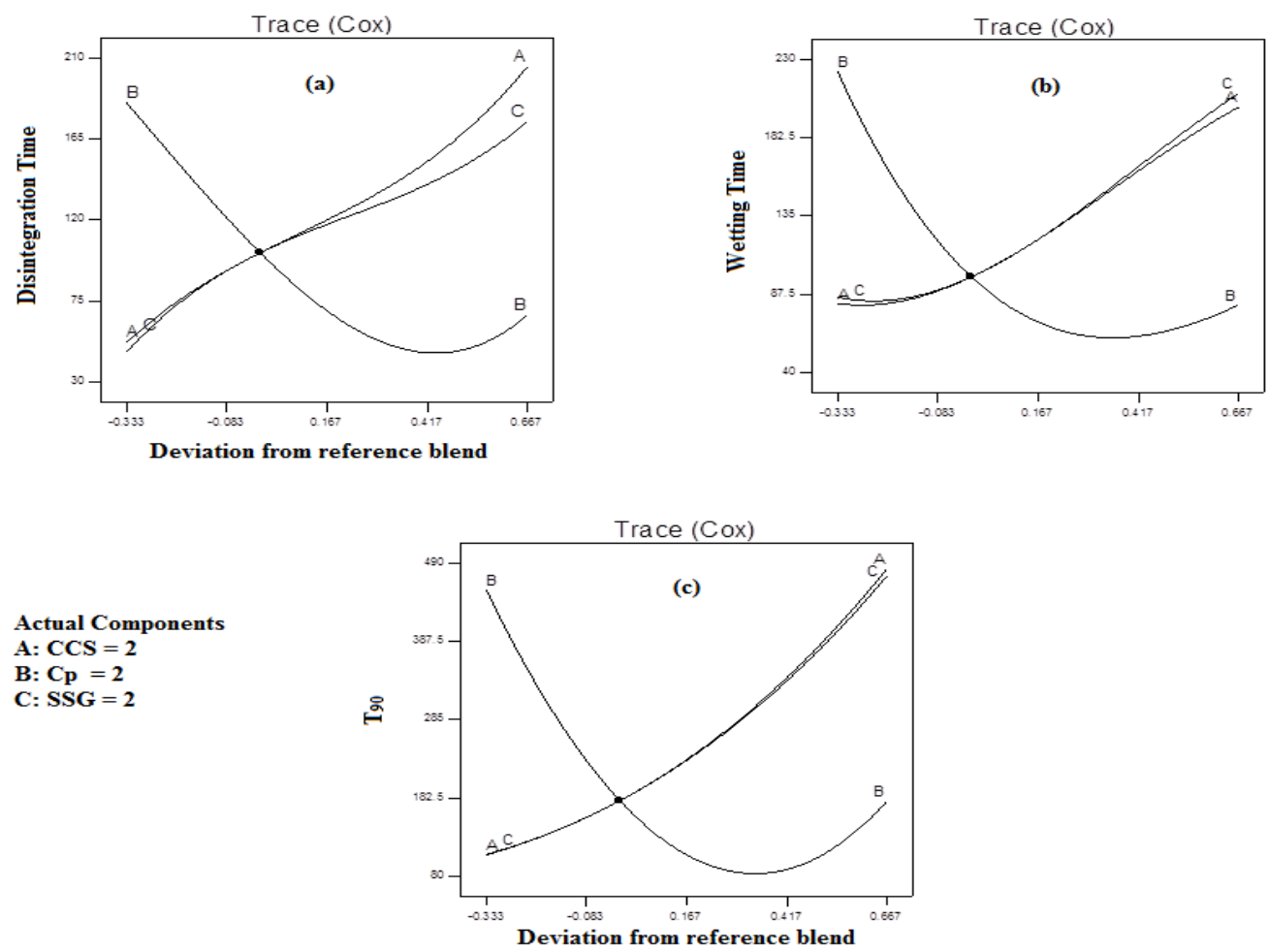

Figure (3): Effect of CCS $\left(\mathrm{X}_{1}\right), \mathrm{CP}\left(\mathrm{X}_{2}\right)$ and SSG $\left(\mathrm{X}_{3}\right)$ on disintegration time (a), wetting time (b) and $t_{90}$ (c) of vardenafil hydrochloride ODTs.

It can be concluded, from all regression equations 8-10 and figure (3) that the special cubic interaction effect $\left(\mathrm{X}_{1} \mathrm{X}_{2} \mathrm{X}_{3}\right)$ had a great significant ( $\mathrm{p}$-value $\left.<0.05\right)$ effect on disintegration time $\left(\mathrm{Y}_{1}\right)$. Also, it had a great insignificant antagonistic effect on wetting time $\left(\mathrm{Y}_{2}\right)$ with minor effect on $t_{90}\left(\mathrm{Y}_{3}\right)$. Interaction effect $\left(\mathrm{X}_{1} \mathrm{X}_{2}\right)$ had a great significant antagonistic effect on disintegration time $\left(\mathrm{Y}_{1}\right)$ and $t_{90}\left(\mathrm{Y}_{3}\right)$ with little effect on wetting time $\left(\mathrm{Y}_{2}\right)$ as the interaction effect $\left(\mathrm{X}_{2} \mathrm{X}_{3}\right)$ had the highest effect on it more than the other binary interactions. Moreover, interaction effect $\left(\mathrm{X}_{2} \mathrm{X}_{3}\right)$ had a noticeable significant antagonistic effect on $t_{90}\left(\mathrm{Y}_{3}\right)$ and disintegration time $\left(\mathrm{Y}_{1}\right)$, while, $\left(\mathrm{X}_{1} \mathrm{X}_{3}\right)$ had insignificant effect on all responses. According to the individual variables $X_{1}$ had the highest synergistic effect on the three responses and $X_{2}$ had the least effect.

\section{Analysis of fitted data}

Response surface plots (Figure 4) are graphically representing the regression equations 3-5 showing the effect of CCS $\left(\mathrm{X}_{1}\right), \mathrm{CP}\left(\mathrm{X}_{2}\right)$ and $\operatorname{SSG}\left(\mathrm{X}_{3}\right)$ on the disintegration time, wetting time and $\mathrm{T}_{90}$ of vardenafil hydrochloride ODTs. By visual observation of the plots, it can be seen that they nearly have the same pattern indicating a marked decrease in disintegration time, wetting time and $t_{90}$ by increasing the concentration of $\mathrm{CP}$ and reached their minimum values at a concentration around $4.24 \%$, thereafter, increase slightly to the concentration of $6 \%$ of CP. This results are in accordance with Prajapati and Patel (Prajapati and Patel 2010) who studied the different behavior of wetting time, in-vitro disintegration time and cumulative $\%$ drug released of piroxicam ODTs prepared by different superdisintegrants using water soluble filler (Mannitol). They concluded that 
the crospovidone can be successfully utilized for preparation of ODTs. This may be due to crospovidone swell by $95 \%$ to $120 \%$ upon contact with water; in addition, during tablet compaction the highly compressible crosspovidone particles become extremely deformed. As the deformed crosspovidone particles come in contact with water that is wicked into the tablet, the particles recover their normal structure and then swell, resulting in rapid volume expansion and high hydrostatic pressures that cause tablet disintegration (Balasubramaniam et al. 2008). Moreover, Zade, Kawtikwar et al. investigated the effect of type and concentration of the disintegrants (Croscarmellose Sodium, Sodium starch glycolate and crospovidone) on tizanidine ODTs properties. They concluded that tablets prepared using $5 \%$ of crosspovidone had the least disintegration time among tablets prepared by direct compression method (Zade et al. 2009). On the other hand CCS showed increased disintegration time and wetting time due to it works mainly by wicking mechanism and according to Lopez-Solis and Villafuerte-Robles high hygroscopic disintegrants will be inhibited by other high water consuming formula components (e.g. dextrates) (Lopez-Solis and Villafuerte-Robles 2001). Besides, water soluble fillers causes increase in viscosity of the penetrating fluids which tends to reduce effectiveness of disintegrating agents and as they are water soluble, they are likely to dissolve rather than disintegrate (Gopinath et al. 2012).

Figure (5) represent the in vitro dissolution profiles of vardenafil hydrochloride from different ODTs formulations. It can be seen that the formula 4, 6 and 7 showed the fastest dissolution profiles as they released the highest drug concentration after 3 minutes followed by formula 2 and 9 which showed slower dissolution rate giving the maximum drug dissolution after 4 and 5 minutes respectively. Formulations 1, 3, 5, 8 and 10 showed the lowest dissolution rate $(66.78 \%, 65.46 \%, 73.34 \%, 83.21$ and $86.40 \%)$ respectively, after 5 minutes. These results are in accordance with Battu, Repka et al who studied the effect of varying concentrations of different superdisintegrants on disintegration time and in vitro dissolution profiles of different rapidly disintegrating fenoverine tablets. They found that release of drug was faster from formulations containing $6 \%$ crospovidone compared to other formulations (Battu et al. 2007).

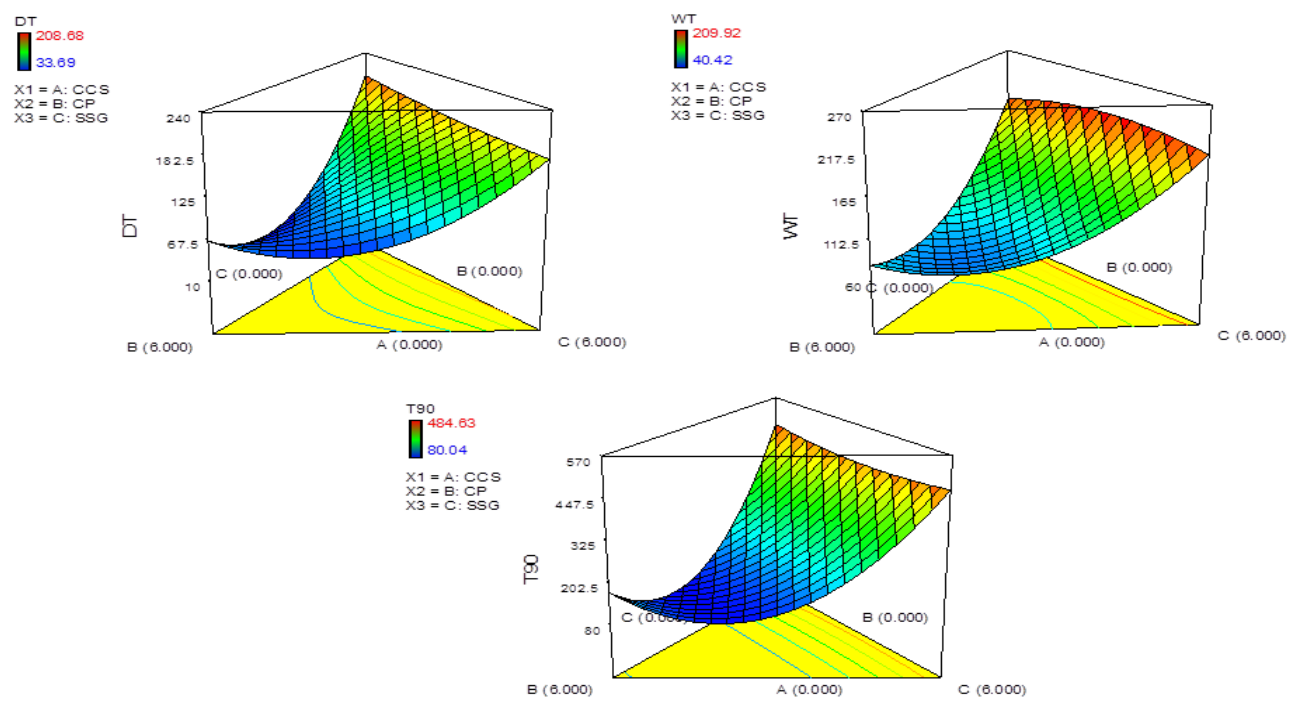


Figure (4): Response surface plot estimating the effect of CCS $\left(\mathrm{X}_{1}\right), \mathrm{CP}\left(\mathrm{X}_{2}\right)$ and SSG $\left(\mathrm{X}_{3}\right)$ on the disintegration time (a), wetting time (b) and $t_{90}(\mathrm{c})$ of vardenafil hydrochloride ODTs.

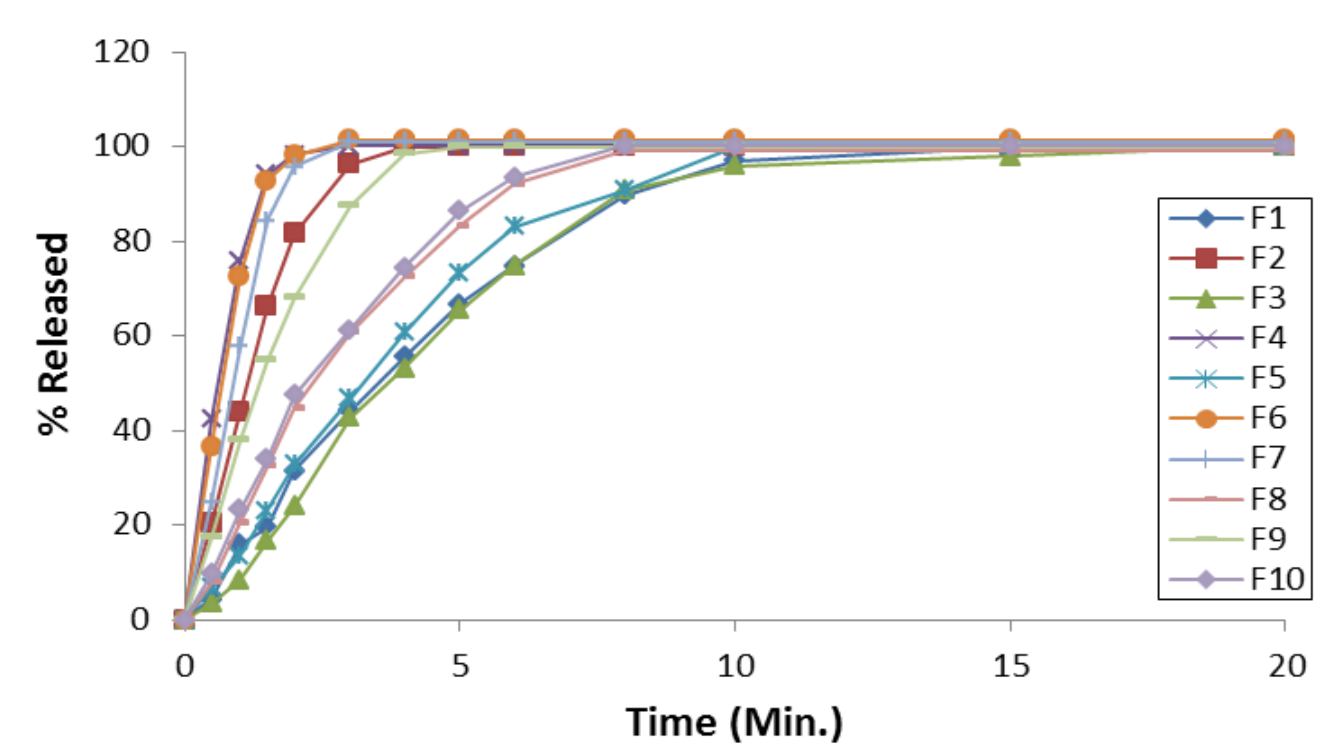

Figure (5): Dissolution profile of different vardenafil hydrochloride ODTs formulations.

\section{Model validation and optimization of the formualtion parameters}

To validate the regression equations or model, a check point of $\mathrm{X} 1=1.72 \%, \mathrm{X} 2=$ $4.28 \%$ and $\mathrm{X} 3=0 \%$ was selected. The predicted and observed values of disintegration time, wetting time and time for $90 \%$ release of the tablets for the check point were in close agreement with the values predicted by the model, Figure (6). Concentration of CCS and $\mathrm{CP}$ that showed the lowest disintegration time, wetting time and $\mathrm{t}_{90}$ were chosen as the optimum concentration as shown in Table (6). Optimization was carried out using multiple response optimization. Optimum concentration was verified from the contour plots of all responses. At this optimum concentration, oral disintegrating tablets showed a disintegration time of $33.69 \mathrm{sec}$. (predicted) and $34.27 \pm 1.913 \mathrm{sec}$. (observed), a wetting time of $70.07 \mathrm{sec}$. (predicted) and $73.12 \pm 2.520 \mathrm{sec}$. (observed) and T90 of $82.81 \mathrm{sec}$ (predicted) and 81.33 (observed). 


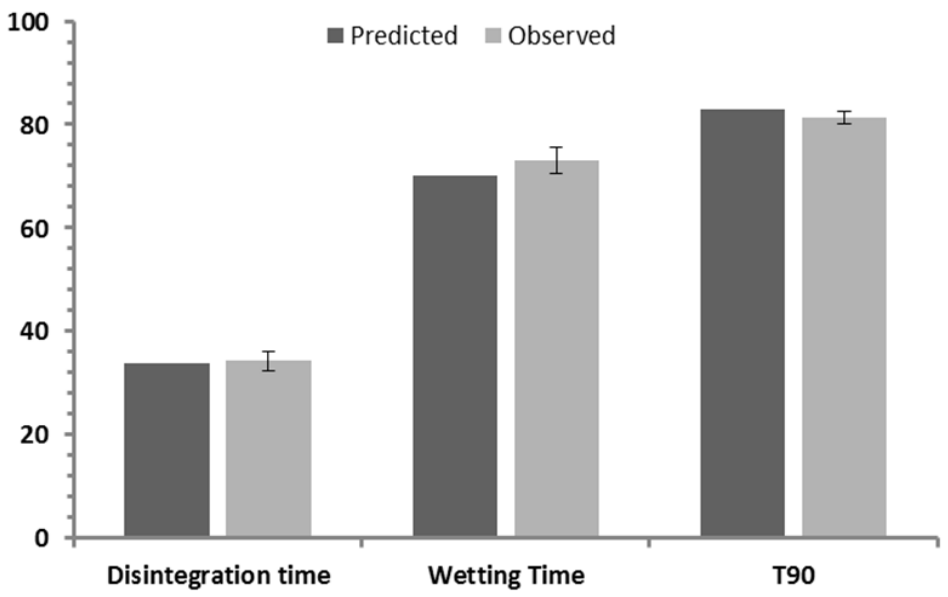

Figure (6): Comparison of predicted and observed values of disintegration, wetting time and $\mathrm{T}_{90}$ for check point of vardenafil hydrochloride ODTs.

Table (6): Optimized vardenafil hydrochloride ODTs formula.

\begin{tabular}{|c|c|c|}
\hline Ingredient & \multicolumn{2}{|c|}{ Weight $^{\mathrm{a}}(\%)$} \\
\hline Vardenafil $\mathrm{HCl}$ & \multicolumn{2}{|l|}{11.85} \\
\hline \multirow{3}{*}{ Superdisintegrants } & Crosscarmellose Sodium & 1.72 \\
\hline & Crospovidone & 4.28 \\
\hline & Sodium Starch Glycolate & 0 \\
\hline Dextrates (Emdex®) & \multicolumn{2}{|l|}{40} \\
\hline Sodium Stearyl Fumarate & \multicolumn{2}{|l|}{0.5} \\
\hline Mannitol & \multicolumn{2}{|l|}{ To 100} \\
\hline
\end{tabular}

\section{Stability study of the optimized ODTs formula}

The optimized formula was selected for studying the effect of storage on tablet physical properties and drug release. Figure (7) showed the disintegration time and hardness of the optimized ODTs formula before and after storage under accelerated conditions for three months. Also, table (7) showed the percent remained of vardenafil hydrochloride from the selected formulation after storage at $40 \pm 2{ }^{\circ} \mathrm{C}$ and $75 \pm 5 \%$, relative humidity.

It is clear from Figure (7) that the disintegration time of the selected formula was not significantly affected by storage under accelerated conditions. On the other hand, the hardness was significantly increased from $2.25 \pm 0.058 \mathrm{Kp}$ to $2.77 \pm 0.071 \mathrm{Kp}$. Those results are in accordance with shukla and price who studies the effect of moisture content on the crushing force of dextrates. They found that dextrates crushing force was increased dramatically by increasing the moisture content due to the moisture improves bonding 
between particles of dextrates (Shukla and Price 1991). Moreover, Table (7) showed that the percent remained of vardenafil hydrochloride after 90 days was $98.28 \%$ and by calculating the kinetic parameters it is obvious that the degredation of vardenafil hydrochloride was zero order reaction based on the values of correlation coefficient $(r)$ and the $t_{90}$ for the optimized formula was 1.52 years (Samy et al. 2001), table (8).

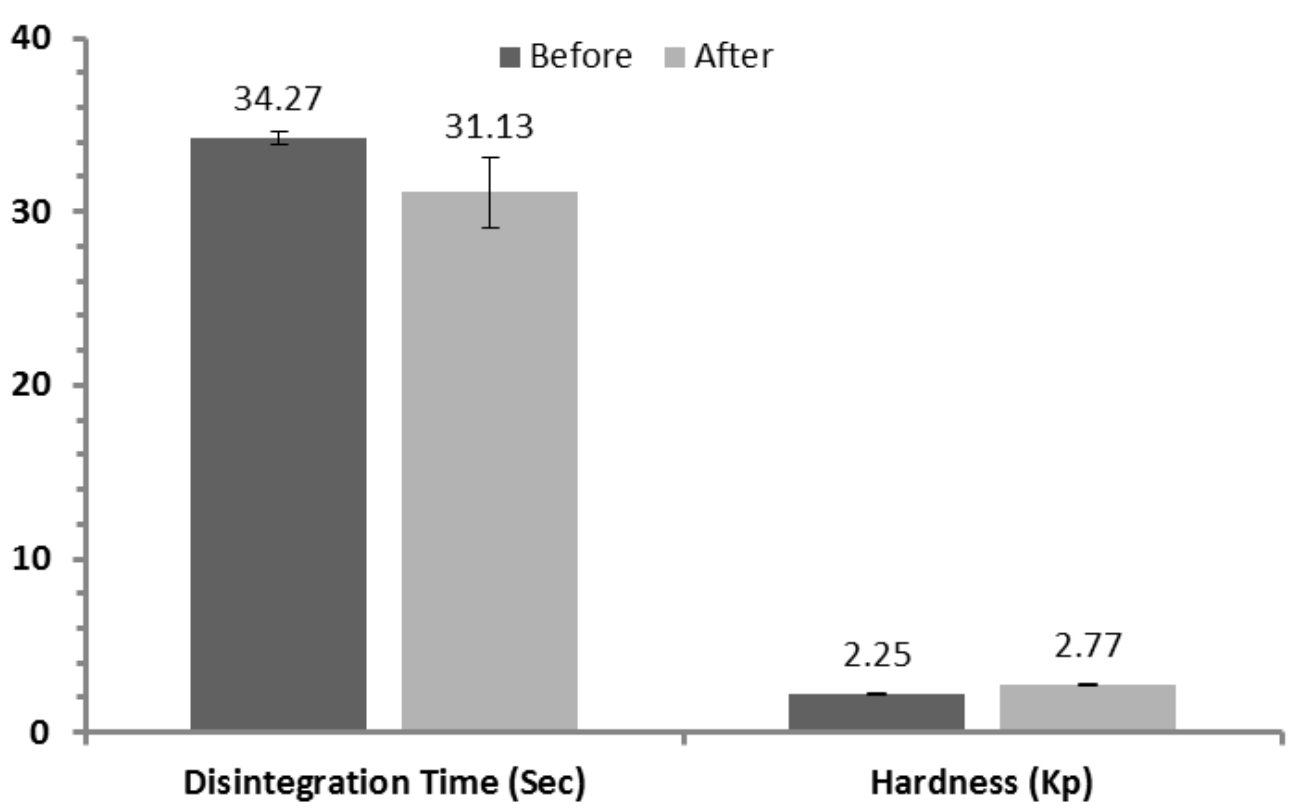

Figure (7): Disintegration time and hardness of vardenafil hydrochloride oral disintegrating tablets (under accelerated conditions).

Table (7): Percent remained of vardenafil hydrochloride at $40 \pm 2{ }^{\circ} \mathrm{C}$ and $75 \pm 5 \%$ relative humidity.

\begin{tabular}{|c|c|}
\hline Time (days) & \% vardenafil hydrochloride remained \pm S.D \\
\hline Initial & $101.02 \pm 0.98$ \\
\hline 14 & $99.63 \pm 0.38$ \\
\hline 30 & $99.12 \pm 0.25$ \\
\hline 60 & $98.87 \pm 0.48$ \\
\hline 90 & $98.28 \pm 0.87$ \\
\hline
\end{tabular}

Table (8): Kinetic parameters of the optimized formula based on accelerated stability testing at $40 \pm 2{ }^{\circ} \mathrm{C}$ and $75 \pm 5 \%$ relative humidity.

\begin{tabular}{|c|c|c|c|c|c|c|}
\hline Model & $\mathbf{r}$ & $\mathbf{A}$ & $\mathbf{b}$ & $\mathbf{K}$ & $\mathbf{t}_{1 / 2}$ (days) & $\mathbf{t}_{90}$ (days) \\
\hline Zero & $\mathbf{0 . 9 8 0 7}$ & $\mathbf{0 . 1 1 9 7}$ & $\mathbf{0 . 0 1 8 1}$ & $\mathbf{0 . 0 1 8 1}$ & $\mathbf{2 7 7 0}$ & $\mathbf{5 5 4}$ \\
\hline
\end{tabular}




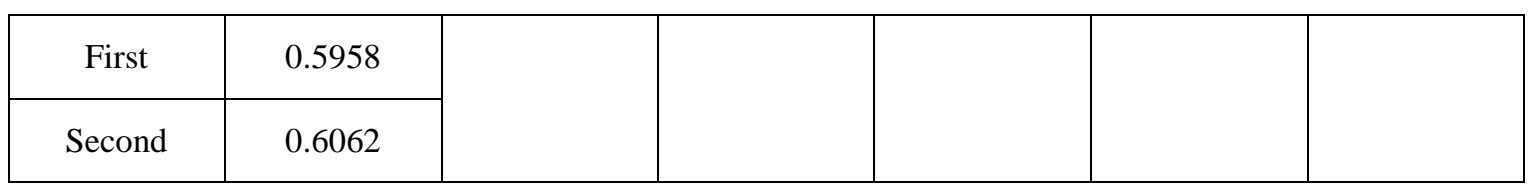

\section{Comparing the optimized ODTs formula with Prosolv ${ }^{\circledR}$ ODT as a ready ODT} system

Figure (8) showed the properties of both optimized and Prosolv ${ }^{\circledR}$ ODT tablets. It is clear from the figure that the optimized ODTs formula had a very significant lower disintegration time, wetting time and $t_{90}$. Additionally, it was clear from the dissolution profiles of both formulations that the optimized formula gave significant higher dissolution rate than Prosolv ${ }^{\circledR}$ ODT Figure (9).

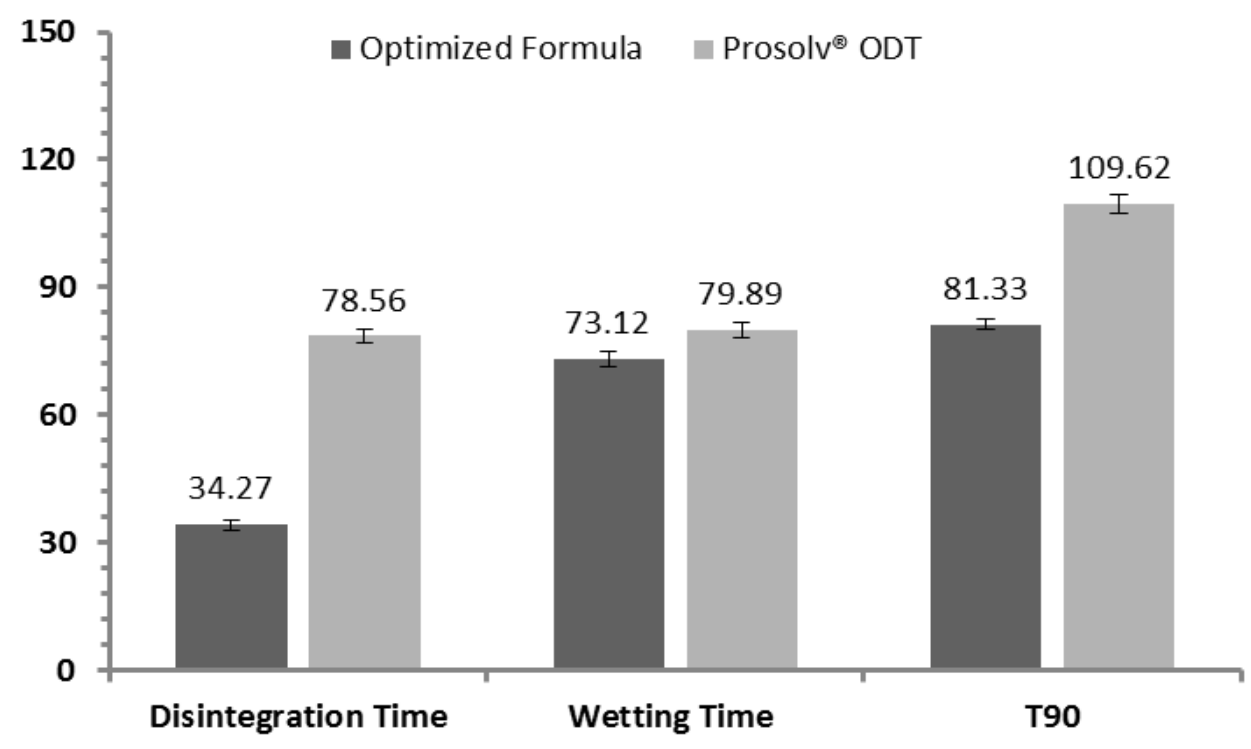

Figure (8): Properties of vardenafil hydrochloride ODTs and Prosolv ${ }^{\circledR}$ ODT (a ready ODT system).

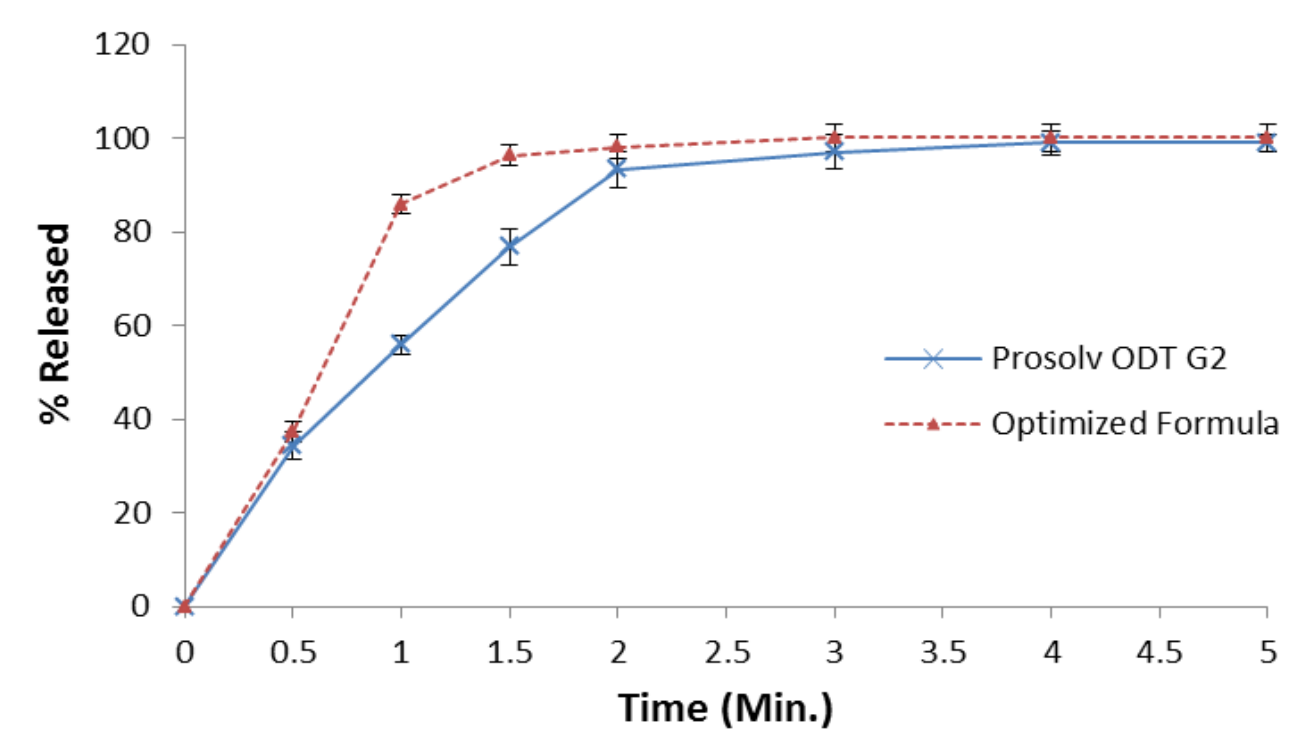


Figure (9): Dissolution profiles of vardenafil hydrochloride ODTs and Prosolv ${ }^{\circledR}$ ODT (a ready ODT system).

\section{Conclusion}

Vardenafil hydrochloride ODTs were successfully prepared using direct compression method. The composition of ODTs could be optimized using a simplex centroid mixture design so as to obtain rapid disintegration, wettability and drug dissolution along with acceptable tablets hardness and friability. Furthermore, the stability study results of optimized batch indicate that there is no alteration after storage. Also, by comparing the optimized formula with Prosolv ${ }^{\circledR}$ ODT it showed significant lower disintegration time and higher dissolution rate. This could enhance drug absorption and bioavailability with a rapid onset of action, resulting in improved patient compliance and convenience. It can be concluded from the results of the optimization study that ODTs containing water soluble filler and binder like dextrates and mannitol can be formulated successfully using superdisintegrants crospovidone in combination with crosscarmellose sodium.

\section{REFERENCES}

Abdelbary, A., Elshafeey, A. and Zidan, G. (2009). "Comparative effects of different cellulosic-based directly compressed orodispersable tablets on oral bioavailability of famotidine." Carbohydrate polymers 77(4): 799-806.

Balasubramaniam, J., Bindu, K., Rao, V., Ray, D., Haldar, R. and Brzeczko, A. (2008). "Effect of superdisintegrants on dissolution of cationic drugs." Dissolution Technologies 15(2): 18.

Battu, S. K., Repka, M. A., Majumdar, S. and Rao Y, M. (2007). "Formulation and evaluation of rapidly disintegrating fenoverine tablets: effect of superdisintegrants." Drug development and industrial pharmacy 33(11): 1225-1232.

Cousin, G., Bruna, E. and Gendrot, E. (1995). Rapidly disintegratable multiparticular tablet, Google Patents US20060134195 A1.

Dobetti, L. (2001). "Fast-melting tablets: Developments and technologies." Pharmaceutical Technology 25(9; SUPP): 44-50.

DrugBank (2016). DrugBank: Vardenafil.

DrugDetails. (2016). "Vardenafil $\quad \hat{a} \square$ “ $\quad$ Drug $\quad$ Details." $\quad$ from http://drugsdetails.com/vardenafil/.

Fu, Y., Yang, S., Jeong, S. H., Kimura, S. and Park, K. (2004). "Orally fast disintegrating tablets: developments, technologies, taste-masking and clinical studies." Critical Reviews ${ }^{\mathrm{TM}}$ in Therapeutic Drug Carrier Systems 21(6), 433-76.

Ganesh, N. and Deshpande, K. (2011). "Orodispersible tablets: An overview of formulation and technology." International Journal of Pharma and Bio Sciences 2(1): 726-734.

Ghosh, T., Ghosh, A. and Prasad, D. (2011). "A review on new generation orodispersible tablets and its future prospective." International journal of pharmacy and pharmaceutical sciences 3(1): 1-7. 
Gopinath, H., Shanmugasundaram, S. and Bada, P. (2012). "Disintegrants-a brief review." J. Chem. Pharm. Sci 5: 105-112.

Hirani, J. J., Rathod, D. A. and Vadalia, K. R. (2009). "Orally disintegrating tablets: a review." Tropical Journal of Pharmaceutical Research 8(2) 161 -172.

Jagadish, B., Yelchuri, R., Tangi, H., Maroju, S. and Rao, V. U. (2010). "Enhanced dissolution and bioavailability of raloxifene hydrochloride by co-grinding with different superdisintegrants." Chemical and Pharmaceutical Bulletin 58(3): 293-300.

Jonwal, N., Mane, P., Mokati, S. and Meena, A. (2010). "Preparation and in vitro evaluation of mouth dissolving tablets of domperidone." Int. J. Pharm. Pharm. Sci 3: 975-1491.

Lopez-Solıs, J. and Villafuerte-Robles, L. (2001). "Effect of disintegrants with different hygroscopicity on dissolution of Norfloxacin/Pharmatose DCL 11 tablets." International journal of pharmaceutics 216(1): 127-135.

Mostafa, H. F., Ibrahim, M. A. and Sakr, A. (2013). "Development and optimization of dextromethorphan hydrobromide oral disintegrating tablets: effect of formulation and process variables." Pharmaceutical development and technology 18(2): 454463.

Prajapati, B. G. and Patel, B. (2010). "Formulation, evaluation and optimization of orally disintegrating tablet of piroxicam." Int J Pharm Tech Res 2(3): 1893-1899.

Rahman, S., Al Masum, M. A., Islamand, S. A. and Reza, M. S. (2012). "Formulation and Evaluation of Bi-layered SustainedRelease Matrix Tablets of Tramadol Hydrochloride." Journal of Applied Pharmaceutical Science 2(6): 129.

Samy, A. M., El Say, K. M. and Fetouh, M. I. (2001). "Effect of polymer on the formulation, micromeritc properties, in-vito evaluation and stability testing on ibuprofen microcapsule prepared by the emulsion solvent evaporation technique." Az J. Pharm Sci 28: 267-284.

Sastry, S. V., Nyshadham, J. R. and Fix, J. A. (2000). "Recent technological advances in oral drug delivery-a review." Pharmaceutical science \& technology today 3(4): 138-145.

Shoukri, R. A., Ahmed, I. S. and Shamma, R. N. (2009). "In vitro and in vivo evaluation of nimesulide lyophilized orally disintegrating tablets." European Journal of Pharmaceutics and Biopharmaceutics 73(1): 162-171.

Shukla, A. J. and Price, J. C. (1991). "Effect of moisture content on compression properties of two dextrose-based directly compressible diluents." Pharmaceutical research 8(3): 336-340.

Suresh, B., Rajendar, K., Ramesh, G. and Yamsani, M. (2008). "Orodispersible tablets: An overview." Asian J Pharm 2(1): 2-11.

USP30-NF25, U. P. (2007). "US Pharmacopoeial Convention." Inc., Rockville, MD, USA.

Van Arnum, P. (2007). "Advancing ODT technology." Pharmaceutical Technology, $31(10), 66-76$ 
Velmurugan, S. and Vinushitha, S. (2010). "Oral disintegrating tablets: An overview." International Journal of Chemical and Pharmaceutical Sciences 1(2): 1-12.

Wagh, M. A., Kothawade, D. P., Salunkhe, K. S., Chavan, N. V. and Daga, V. R. (2010). "Techniques used in orally disintegrating drug delivery system." International journal of drug delivery 2(2) 98 - 196.

Zade, P., Kawtikwar, P. and Sakarkar, D. (2009). "Formulation, evaluation and optimization of fast dissolving tablet containing tizanidine hydrochloride." Int J Pharm Tech Res 1(1): 34-42.

\title{
صياغة وتعظيم عقار قاردينافيل هيدروكلوريد في صورة أقراص سريعة التقتت بالفم : تأثير المواد فائقة التقتت فيورة
}

\author{
للسادة الاكاتزة \\ حسام الدين محمد قدري ، علاء عبد الله زكي ، علاء الدين علي قاسم \\ مسـن
}

قسم الصيدلانيات و الصيدلة الصناعية بجامعة الأز هر

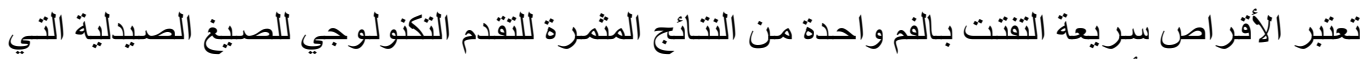

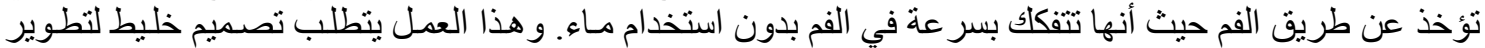

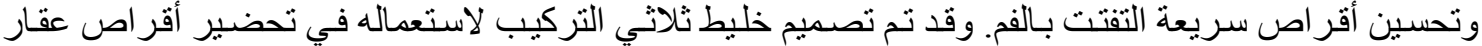

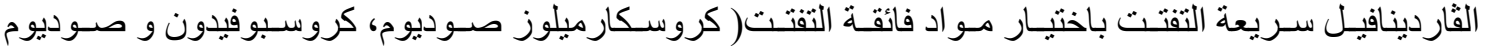

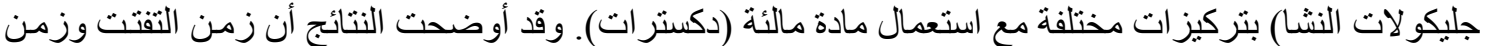

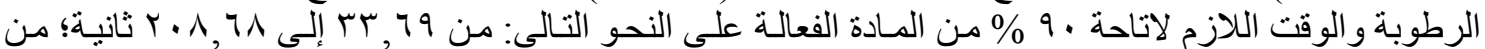

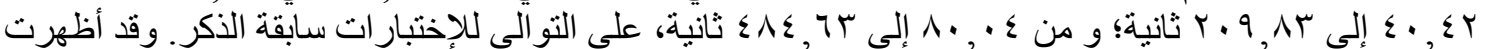

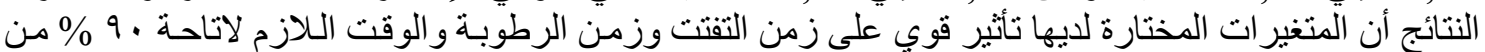

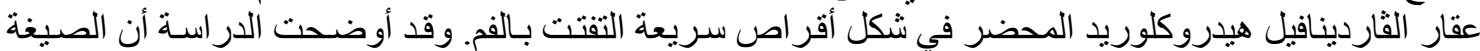

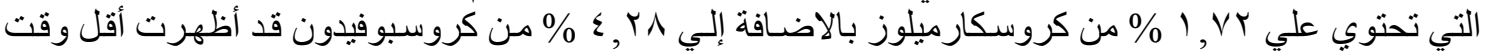

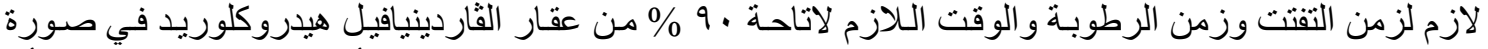

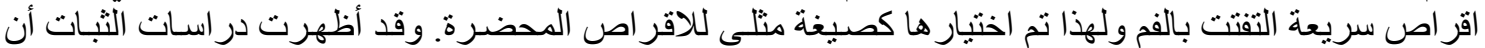

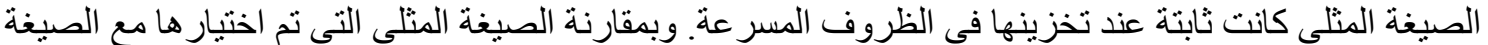

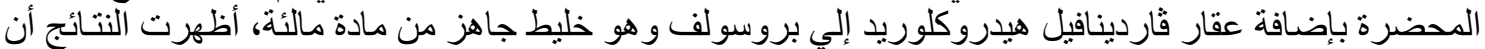

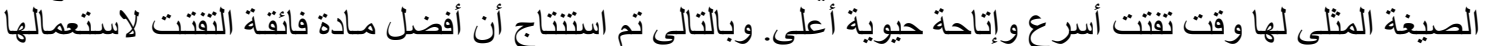

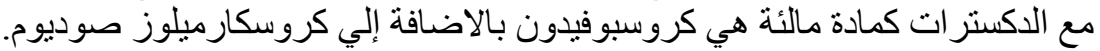

